\title{
Determination of technological risk influences in a port system using DEMATEL
}

\author{
Claudia Durán ${ }^{\mathrm{a}^{*}}, \mathrm{Juan}_{\text {Sepulveda }}{ }^{\mathrm{a}}$ and Raúl Carrasco ${ }^{\mathrm{b}, \mathrm{c}}$
}

${ }^{a}$ Departamento de Ingeniería Industrial, Universidad de Santiago de Chile, Santiago, Chile

${ }^{b}$ Facultad de Administración y Economía, Universidad de Santiago de Chile, Santiago, Chile

${ }^{c}$ Facultad de Ingeniería, Ciencia y Tecnología, Universidad Bernardo O'Higgins, Santiago, Chile

\section{H R O N I C L E}

\begin{tabular}{l}
\hline Article history: \\
Received September 16, 2016 \\
Received in revised format: \\
October 22, 2016 \\
Accepted May 1,2017 \\
Available online \\
May 1,2017 \\
\hline Keywords: \\
Technological risk \\
Synergy of system \\
DEMATEL \\
Strategic planning \\
Process of information \\
\hline
\end{tabular}

Article history:

Received September 16, 2016

October 22, 2016

Accepted May 1, 2017

Available online

Technological risk

nergy of system

Process of information

\section{A B S T R A C T}

There is a little research about the relationship between risk and technology by using the DEMATEL model in a complex systems such as maritime port. Those studies neither include nor identify the relationships of technological risk generated between a Port Community and all the other actors who interact with it. This study presents the potential advantage of applying the DEMATEL to identify the synergic relationships at strategic and business levels produced by technological risk. The results determine the causes and the effects of decisions made by managers of port engineering community. They also affect the processes of information and communication logistics chains' export and import.

(C) 2018 Growing Science Ltd. All rights reserved.

\section{Introduction}

Decision Making Trial and Evaluation Laboratory Model (DEMATEL) is used as a tool that helps decision making of engineering management. Its development can emphasize the selection, ranking and grouping of strategies and it can manage proposed improvements and actions to enhance the development of strategic management, to make a more efficient use of the resources of a company $(\mathrm{Hu}$ et al., 2011; Lin et al., 2011; Wang et al., 2012). DEMATEL concept has been used since 1972 for quantitative processing of people's perceptions, to help represent and analyze mental maps of information according to the requirements and objectives defined by the organization being a priority the effective use of information where knowledge and reasoning have a very important role. It has been associated with a problem-solving method for evaluating qualitative-quantitative information (Chiu et al., 2006; Hemati et al., 2012; Moghaddam et al., 2011). In this article model will be the main theme.

\footnotetext{
* Corresponding author.

E-mail address: claudia.duran@usach.cl (C. Durán)

C 2018 Growing Science Ltd. All rights reserved. doi: 10.5267/j.dsl.2017.5.002
} 
This study addresses an unexplored field in the area of decision-making at the management level of a Chilean medium-sized maritime port, comprising private companies, public organizations, trade unions and social groups. It discusses a new paradigm that shows the link between two aspects of the macroenvironment: technology and risk, where engineering decisions are made to improve efficiency/ effectiveness of the daily operational activities (Durán \& Córdova, 2016; Knowles, 2014; Stankiewicz, 2009; Zhong et al., 2011).

This paradigm facilitates the analysis of decisions related to technology-risk, linked to the information technology process of an organization. It is noteworthy that these concepts are often studied separately by setting a link between technology/decision-making or risk/decision-making; for instance, some authors use multi-criteria methods to manage and evaluate competitive strategies as well as information technology (IT) projects; also other authors suggest models and methodologies to control risk management of IT (Chien et al., 2014; Poveda-Bautista et al., 2012; Rodríguez et al., 2017; Todt \& Luján, 2008; Zhong et al., 2011).

Some questions arise: how can the Port Community and especially those involved in engineering improve port efficiency and effectiveness at individual and collective levels by applying DEMATEL? How is technological risk identified in the strategies and objectives of the Port Community? What synergies exist in technological risk generated by the Port Community and port companies? Can the model determine the synergy of technological risk? What are the gaps between DEMATEL and information technology processes? This research will propose a useful model, validated by groups of port experts, to answer these questions.

\subsection{Brief bibliographic analysis}

DEMATEL is used because it helps to clearly describe complex systems, to analyse cause-effect influences that may exist between two variables, to identify strengths and weaknesses of strategic objectives; it can design strategic maps to improve strategic mapping processes; it can choose and rank criteria to accomplish at a more efficient and effective management in an organization; for example, it can be applied to innovate in ICTs and control systems (Chiu et al., 2006; Falatoonitoosi et al., 2013; Hemati et al., 2012; Moghaddam et al., 2011; Sumrit \& Anuntavoranich, 2013). The model is a strong decision method that permits the integration of expert opinion to evaluate management by grouping cause and effect indicators in the context of Balanced Scoredcard (Malina et al., 2007; Wu, 2012; Wu \& Lee, 2007).

In relation to management and evaluation of technological risk, some studies have focused on the existing risks in the technology application, on the information processes, in the information security of business and governance of an enterprise, other risks are produced by failure in ICT and operational management; also those implicit risks in technological innovation, affecting governance and stakeholders' decision making, and those risks produced by the interactions of multiple technological networks among different public and private actors (Bayaga \& Flowerday, 2012; Orman, 2013; Piggin, 2014; Renn \& Benighaus, 2013; Scheer, 2013; Young, 2016). It should be observed that there is no research on sea ports identifying and evaluating the impact of technological risk on business and strategic decisions.

Concerning synergy, it is possible to set a link of risk between actors when there is information transference in a network of organizations; therefore, the greater the synergy in a network of actors, the greater the risk level to be assumed by an individual actor (Wei, 2010). In regard to ports, synergy in the risk aspect is expressed under the following the pairs of relationships: the port logistics and the urban economy; the port development and the environmental protection, the maritime safety laws and the public policies, the civil and military maritime safety activities, the container terminals and the 
continental platform (Katsigeras, 2011; Zhong et al., 2011). With regard to technology, synergy is achieved by sharing information, the collective intelligence, the specialized skills and tools that can be combined in an organized system (Corning, 2003; Durán \& Córdova, 2016). Technological synergy is also possible when there is technological innovation, quality improvement and e-business; an organization showing higher technological synergy will have better coordination than another one having basic technology (Bank, 2008; Durán \& Córdova, 2015, 2016; Wei, 2010; Zhong et al., 2011). It is worth noting that there is no research identifying and evaluating synergy of technological risk in sea ports.

\section{Material and methods}

\subsection{Actors having strategic relationships: case of a chilean port system}

Chilean ports are owned by the State, they are mixed ports coordinated by a Port Community comprising private companies under government concession: The Port Authority is the actor who manages and coordinates actions related to the port business core activities and those related to the Externalized and Internal Port Terminals operating in the port. As displayed in Fig. 1, the port community relates to other actors who can exert social/trade regulation on the port system or who may be part of the export or import logistics chain. We can see a port system consisting of various actors of different nature who establish relationships at strategic, tactical and operational level: non-profit and profit private companies providing services, trade associations and social groups.

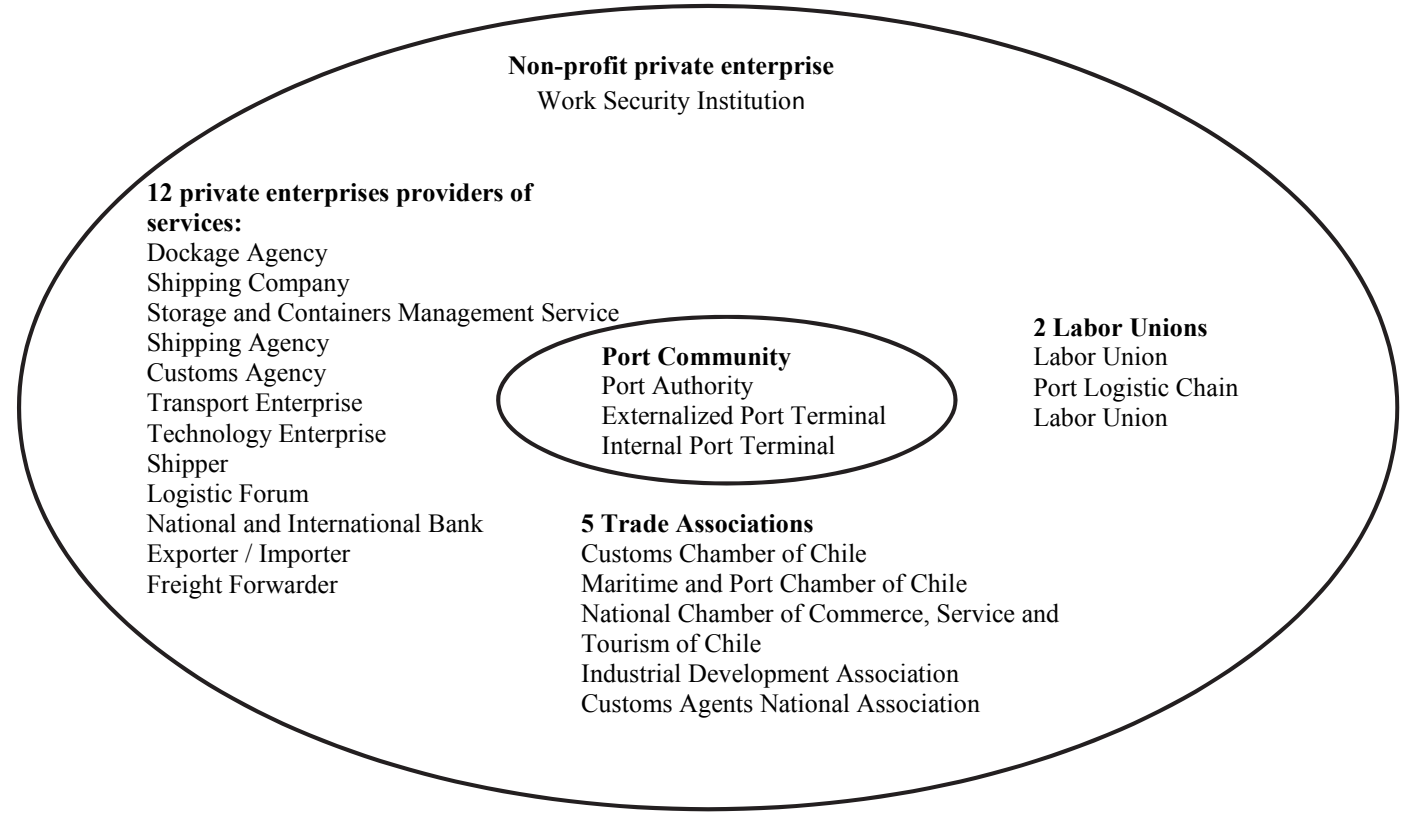

Fig. 1. Private actors integrating the chilean port system

Every actor who is part of the port mixed network also belongs to the macro environment of the Port Community where PESTE (Durán \& Córdova, 2016) synergic strategic relationships may exist. This study will only focus on the technological criteria of PESTE and its possible relationship with the risk criterion.

\subsection{Strategic relationships among private actors linked to risk and technology}

In order to investigate the strategic synergy between technology and risk criteria, Table 1 presents strategic phrases related to technology or risk from each private actor integrating the Chilean port 
system. The strategic phrases are related to technological innovation and linked to the multimodal logistic connectivity; they are classified as "technological" criterion. Then, if the actors' strategic phrases express a search for steadiness in the port system while providing timely and reliable strategic solutions, if their phrases express concern for the port security, if actors from the import/export logistics chain present any lack of coordination and/or reliability in their activities, they are matched to the risk criteria; likewise, there may be strategic risk if the actor states in his/her generic mission to be linked to trade associations.

Table 1

Port private actors declaring technological and/or risk criteria in their strategic phrases

\begin{tabular}{|c|c|c|c|c|}
\hline & Actor & Strategic phrases & $\begin{array}{l}\text { Multi-criteria } \\
\text { classification }\end{array}$ & Cause of classification \\
\hline \multirow[t]{2}{*}{$\overline{\mathrm{A} 1}$} & Port Authority & $\begin{array}{l}\text { "To ensure the provision of port services to the } \\
\text { logistics chain ... in a framework of permanent } \\
\text { innovation and sustainable development." }\end{array}$ & Technological & $\begin{array}{l}\text { Technological innovation and } \\
\text { multimodal logistics } \\
\text { connectivity }\end{array}$ \\
\hline & & & Risk & Coordination of logistics chain \\
\hline A2 & $\begin{array}{l}\text { Externalized Port } \\
\text { Terminal }\end{array}$ & $\begin{array}{l}\text { "Being part of the customer logistics chain } \\
\text { through a service platform in accord to its } \\
\text { requirements, with high levels of service quality, } \\
\text { innovation and technology." }\end{array}$ & Technological & $\begin{array}{l}\text { Technological innovation and } \\
\text { multimodal logistics } \\
\text { connectivity }\end{array}$ \\
\hline A3 & Internal Port Terminal & "To manage and operate the port terminal." & Technological & $\begin{array}{l}\text { Technological innovation and } \\
\text { multimodal logistics } \\
\text { connectivity }\end{array}$ \\
\hline A4 & Customs Agency & $\begin{array}{l}\text { "To offer clients a comprehensive service before } \\
\text { customs, managing procedures and advising on } \\
\text { banking, transport, and insurance issues ..." }\end{array}$ & Technological & $\begin{array}{l}\text { Technological innovation and } \\
\text { multimodal logistics } \\
\text { connectivity }\end{array}$ \\
\hline A5 & Shipping Agency & $\begin{array}{l}\text { "To provide innovative port services } \\
\text {...comprehensive logistics services ... for the } \\
\text { purpose of creating value for our customers, } \\
\text { employees and shareholders ..." }\end{array}$ & Technological & $\begin{array}{l}\text { Technological innovation and } \\
\text { multimodal logistics } \\
\text { connectivity }\end{array}$ \\
\hline A6 & Shipper & $\begin{array}{l}\text { "The ship owner company which performs } \\
\text { maritime transfer service of physical goods." }\end{array}$ & Risk & Transport of physical goods \\
\hline A7 & $\begin{array}{l}\text { National and } \\
\text { International Bank }\end{array}$ & $\begin{array}{l}\text { "To provide suitable, flexible, reliable and } \\
\text { excellent products and financial services to } \\
\text { businesses, families and institutions." }\end{array}$ & Risk & Reliability of financial services \\
\hline A8 & $\begin{array}{l}\text { Maritime and Port } \\
\text { Chamber of Chile }\end{array}$ & $\begin{array}{l}\text { "To coordinate and manage the dynamics of } \\
\text { foreign trade between public and private } \\
\text { enterprises." }\end{array}$ & Risk & Link with trade organization \\
\hline A9 & $\begin{array}{l}\text { National Chamber of } \\
\text { Commerce, Service } \\
\text { and Tourism of Chile }\end{array}$ & $\begin{array}{l}\text { "To lead the development of our partners } \\
\text { through trade union management, guiding them } \\
\text { towards obtaining the necessary resources to } \\
\text { improve their entrepreneurship and social } \\
\text { responsibility ..." }\end{array}$ & Risk & Link with trade organization \\
\hline A10 & $\begin{array}{l}\text { Customs Chamber of } \\
\text { Chile }\end{array}$ & $\begin{array}{l}\text { "To contribute to the development of our } \\
\text { partners through trade union activity ... } \\
\text { strengthening the unity of the sector..." }\end{array}$ & Risk & Link with trade organization \\
\hline A11 & Transport Enterprise & $\begin{array}{l}\text { "To provide logistics solutions for cargo and } \\
\text { containers, designed to deliver a fast, efficient } \\
\text { and safe service..." }\end{array}$ & Risk & Coordination of logistics chain \\
\hline A12 & $\begin{array}{l}\text { Technological } \\
\text { Enterprise }\end{array}$ & $\begin{array}{l}\text { "To contribute to the technological development } \\
\text { of organizations, facilitating the flow of } \\
\text { information and generating knowledge to } \\
\text { improve decision-making." }\end{array}$ & Technological & Technological Innovation \\
\hline A13 & Exporter / importer & $\begin{array}{l}\text { "To create niche markets and establish business } \\
\text { relationships with national and international } \\
\text { clients ..." }\end{array}$ & Risk & $\begin{array}{l}\text { Commercial coordination with } \\
\text { national and foreign clients }\end{array}$ \\
\hline A14 & Freight Forwarder & $\begin{array}{l}\text { "To provide customers high quality, efficient, } \\
\text { and reliable solutions for maritime and land } \\
\text { transport ..." }\end{array}$ & Risk & $\begin{array}{l}\text { Transportation coordination by } \\
\text { land and sea }\end{array}$ \\
\hline A15 & $\begin{array}{l}\text { Port, Logistics Chain, } \\
\text { Truck Drivers, } \\
\text { Exporters, Shippers, } \\
\text { Customs Agency, and } \\
\text { Labour Unions }\end{array}$ & $\begin{array}{l}\text { "To ensure safety and welfare to all workers } \\
\text { affiliated to the organization." }\end{array}$ & Risk & Link with labour organization \\
\hline
\end{tabular}

It can be observed that only the Port Authority, playing the role of governance, has declared both risk and technology aspects, so it is the only actor generating strategic synergy related to the macroenvironment aspects under research (Bank, 2008; Durán \& Córdova, 2015, 2016). It is worth noting that the other actors of the port system declare only one of the criteria; instead, it is necessary that both 
criteria be stated in their strategic purposes since the development and integration of technology could diminish the existing percentage of risk; particularly, the risks involved in action coordination between the Port Community and private enterprises of import/export outsourced logistics services; these could be diminished if actors' strategic statements and actions involved inter-operative technological platforms and e-business/e-commerce technologies. It should be noted that the existing influence between technological and risk aspects of the macro environment cannot be identified from the available strategic phrases. The results were validated by an expert panel comprising high-level managers and executive officers from the Port Community.

\subsection{Tactical/operational relationships among private actors linked to risk and technology}

As shown in Fig. 2, technological and/or risk strategic level criteria can be aligned to both strategic and operational objectives of port actors of the network, and they can be classified according to their associated attributes or characteristics (Espinosa \& Salinas, 2013; Kaplan \& Norton, 2001; Wu et al., 2010). The attributes shown in Table 2 are part of the Port Community Business Model; they show the need of collaboration, coordination and transference of reliable and timely physical and information resources between the Port Community and the other actors integrating the port system, to carry out its operational activities. Likewise, they can express, as their purpose, the achievement of relationships linked with intellectual capital. Consequently, they need to make knowledge and information explicit and share them.

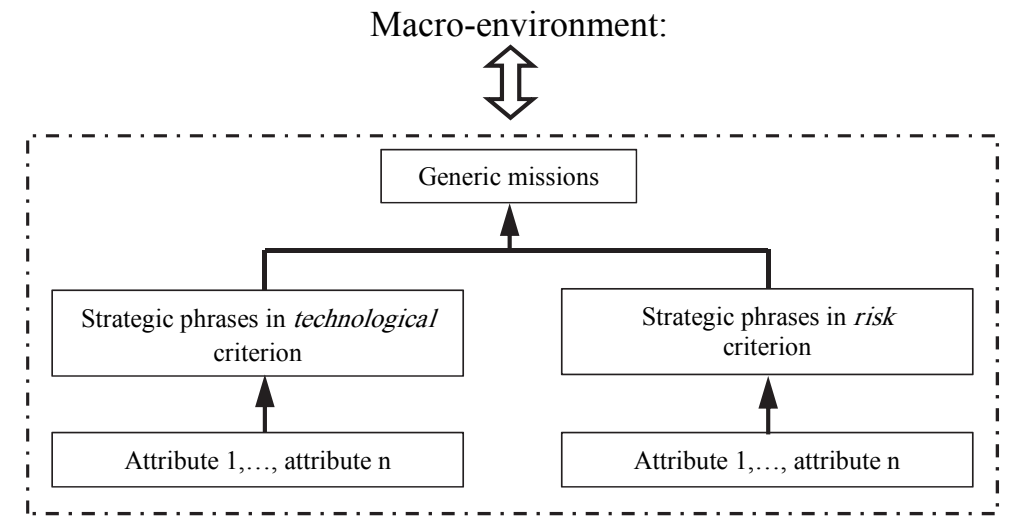

Fig. 2. Relationships at corporate, tactical and operational levels

Table 2

Classification of causes or attributes at tactical and operational levels, generating technological and risk criteria in the port system

\begin{tabular}{ll}
\hline Multicriteria classification & Attribute of tactical and/or operational level \\
\hline Technological & Inter-operative platform systems \\
& Coordination of business lines with Technology Processes \\
& Information management with Communication and Technology Processes \\
& Control and security of cargo transported \\
& Technological investment for connectivity and integration of multimodal logistics \\
& Innovation in technological processes \\
& Asymmetric information transfer between two actors \\
Risk & Imposition of pricing and tariff policies \\
& Fair control, lacking transparency in compliance \\
& Coordinated actions of an actor or group of actors to harm the Port Community \\
& Lack of explicit knowledge in documentation \\
& Informal trade relations and malpractices \\
& Lack of standards in services related to safety and quality \\
& Access and exit barriers, preventing innovation and new technologies \\
& Contracts reducing free competition \\
\hline
\end{tabular}

On the whole, with the attributes of Table 2, it is possible to identify synergy linked with technological and risk criteria between two actors of the port system, degrees of collaboration/partnership are 
observed. In order to determine the relative weight port experts, who play an executive role in two important Port Communities, assign to the fulfilment of each attribute in each criteria analysed, a Likert scale is designed in Table 3. The indicator and index are calculated for each criterion:

- Degree of compliance.

$i=\frac{\text { Total number of attributes fulfilled }}{6} \quad$ with $i=$ technology criteria

- Degree of compliance

$$
j=\frac{\text { Total number of attributes fulfilled }}{9} \quad \text { with } j=\text { risk criteria }
$$

Table 3

Likert scale for each criterion.

\begin{tabular}{lll}
\hline Degree of attribute & Scale & Semantic value of degree of compliance \\
\hline 4 & $>90 \%$ and $\leq 100 \%$ & Very high \\
3 & $>50 \%$ and $\leq 90 \%$ & High \\
2 & $>30 \%$ and $\leq 50 \%$ & Medium \\
1 & 0 to $30 \%$ & Low \\
0 & 0 & No influence \\
\hline
\end{tabular}

In Table 4 it is observed that perceptions of port experts who belong to the Port Community show a high degree of attribute fulfilment, even though inter-operative integrated platform systems among port actors are still missing; on-line information and documentation concerning the cargo traceability addressed to exporters/importers/Freight Forwarder should be accessed. On the other hand, the State of Chile should increase their investment in highways and port infrastructure, while increasing the elaboration and implementation of technological innovation projects in the port.

\section{Table 4}

Classification of the intensity degree of the technological strategic criterion at tactical/operational level in the port system.

\begin{tabular}{lll}
\hline & Actor & Intensity degree \\
\hline A1 & Port Authority & High \\
A2 & Externalized Port Terminal & High \\
A3 & Internal Port Terminal & Medium \\
A4 & Customs Agency & High \\
A5 & Shipping Agency & High \\
A12 & Technological Enterprise & High \\
\hline
\end{tabular}

Concerning Table 5, actors showing a low degree of risk in their attributes are private transnational enterprises and the Port Authority which coordinates the mixed network. Regarding those actors displaying a high and medium degree of risk, involved trade associations and labour unions.

\section{Table 5}

Classification of the intensity degree of the risk strategic criterion at tactical/operational level in the port system

\begin{tabular}{lll} 
& Actor & Intensity degree \\
\hline A1 & Port Authority & Low \\
A6 & Shipper & Low \\
A7 & National and International Bank & Low \\
A8 & Maritime and Port Chamber of Chile & Medium \\
A9 & National Chamber of Commerce, Service and Tourism of Chile & Medium \\
A10 & Customs Chamber of Chile & Medium \\
A11 & Transport Enterprise & Medium \\
A13 & Exporter / importer & Medium \\
A14 & Freight Forwarder & Low \\
A15 & Labor Union and Logistics Chain Labor Unions & High \\
\hline
\end{tabular}


Concerning synergy of technological risk, it should be mentioned that if technology is explicit and if it is used by every outsourced port service private enterprise, there may be a positive effect; conversely, it may indicate that there are actors exerting power over other actors due to factors such as: existence of information asymmetry, lack of knowledge management, need of improving governance policies of the Port Authority in the network of actors, need of greater innovation in the technological and communication processes, among others. On the other hand, the establishment of new technology promotes more competitiveness in a port system, but it increases risk, mainly, cultural changes that may arise, affecting relationships with labour unions and trade associations.

\section{Results}

\subsection{Application of DEMATEL to strategic synergy in a chilean port system}

DEMATEL is used to analyse qualitative data associated to the characteristics of objectives, it can show the structure of a hierarchical decision problem. With this model, the independence of each attribute and the existing cause-effect linkages with the operational and strategic objectives of port actors can be determined (Espinosa \& Salinas, 2013; Govindan \& Chaudhuri, 2016; Kaplan \& Norton, 2001; Wu et al., 2010).

In order to determine the degree of synergy between two port actors for the criteria of this research, data obtained from the qualitative instrument 'expert opinion', applied to two outstanding Chilean Port Communities, are entered in the squared non-symmetric matrix of technological risk $A_{t}$, according to the Likert scale displayed in Table 6 and 7. Port experts use, for their decision making, the influence degrees produced between risk and technology; that is, the technological risk caused by the absence of an intraoperative platform which may permit more effective transactional-type interactions among the actors in the logistics chain; it is worth noting that the absence of technological integration may prevent them from adopting multichannel systems, standardized, collaborative and integrated in export value chains, trusted by the protection and reliability of trade data and information storage capacity, giving quality of service to users (Durán \& Córdova, 2015).

\section{Table 6}

Likert scale for the technological risk criterion.

\begin{tabular}{lll}
\hline Degree of attribute & Scale & Semantic value of influence degree \\
\hline 4 & $>90 \%$ and $\leq 100 \%$ & Very high, two actors are directly related \\
3 & $>50 \%$ and $\leq 90 \%$ & High, two actors are directly related \\
2 & $>30 \%$ and $\leq 50 \%$ & Low, two actors are conversely related \\
1 & 0 to $30 \%$ & Very low, two actors are conversely related \\
0 & 0 & No influence \\
\hline
\end{tabular}

By using the Matlab tool, the model is applied to the matrix of influence of technological risk $A_{t}$, as shown in Eqs. (3-5).

Matrix $\mathrm{A}_{\mathrm{t}}$ is normalized and $M_{t}=k_{1} * A_{t}$ :

$$
k=\min \left(\left[\frac{1}{\max _{1 \leq i \leq n} \sum_{j=1}^{n}\left|a_{i j}^{t}\right|}\right],\left[\frac{1}{\max _{1 \leq j \leq n} \sum_{i=1}^{n}\left|a_{i j}^{t}\right|}\right]\right) i, j \in\{1, \cdots, 15\}
$$

Calculate total relation matrix " $S$ " and summation in rows and columns:

$$
S_{t}=M_{t}+M_{t}^{2}+M_{t}^{3}+\cdots=\sum_{i=1}^{\infty} M^{i} ; S_{t}=M_{t}\left(I-M_{t}\right)^{-1}
$$


$S_{t}=\left|S_{i j}^{t}\right|_{n * n} \quad i, j \in\{1, \cdots, 6\} ; D_{t}=\sum_{j=1}^{n} S_{i j}^{t} ; \quad R_{t}=\sum_{i=1}^{n} S_{i j}^{t}$

Table 7

Matrix $A_{t}$ shows the degrees of Technological Risk (TR) between two actors at tactical/operational levels in the port system

\begin{tabular}{|c|c|c|c|c|c|c|c|c|c|c|c|c|c|c|c|}
\hline Actors & 11 & $\mathbf{A}_{2}$ & $\mathbf{A}_{3}$ & $\mathbf{A}_{4}$ & $\mathbf{A}_{5}$ & $\mathbf{A}_{6}$ & $\mathbf{A}_{7}$ & $\mathbf{A s}_{8}$ & A9 & $\mathbf{A}_{10}$ & $\mathbf{A}_{11}$ & $\mathbf{A}_{12}$ & $\mathbf{A}_{13}$ & $\mathbf{A}_{14}$ & $\mathbf{A}_{15}$ \\
\hline$\overline{A_{1}}$ & 0 & 4 & 2 & 1 & 4 & 0 & 4 & 2 & 3 & 0 & 3 & 4 & 3 & 4 & 4 \\
\hline $\mathrm{A}_{2}$ & 2 & 0 & 0 & 3 & 3 & 3 & 0 & 2 & 0 & 4 & 3 & 4 & 2 & 0 & 3 \\
\hline $\mathrm{A}_{3}$ & 2 & 3 & 0 & 1 & 4 & 1 & 3 & 4 & 1 & 4 & 3 & 1 & 1 & 1 & 3 \\
\hline $\mathrm{A}_{4}$ & 3 & 3 & 0 & 0 & 2 & 4 & 4 & 4 & 4 & 1 & 0 & 1 & 4 & 3 & 2 \\
\hline $\mathrm{A}_{5}$ & 3 & 4 & 4 & 1 & 0 & 1 & 4 & 3 & 3 & 4 & 0 & 1 & 2 & 2 & 3 \\
\hline $\mathrm{A}_{6}$ & 0 & 4 & 1 & 2 & 2 & 0 & 3 & 1 & 1 & 0 & 3 & 0 & 3 & 2 & 4 \\
\hline $\mathrm{A}_{7}$ & 1 & 4 & 1 & 1 & 3 & 1 & 0 & 2 & 3 & 3 & 1 & 2 & 1 & 2 & 2 \\
\hline $\mathrm{A}_{8}$ & 2 & 1 & 4 & 1 & 3 & 3 & 0 & 0 & 4 & 4 & 1 & 2 & 0 & 2 & 1 \\
\hline $\mathrm{A}_{9}$ & 2 & 0 & 2 & 2 & 1 & 2 & 3 & 2 & 0 & 2 & 1 & 1 & 0 & 2 & 3 \\
\hline $\mathrm{A}_{10}$ & 2 & 0 & 2 & 2 & 4 & 3 & 2 & 2 & 2 & 0 & 3 & 2 & 3 & 1 & 3 \\
\hline $\mathrm{A}_{11}$ & 1 & 0 & 2 & 0 & 3 & 4 & 1 & 0 & 2 & 4 & 0 & 1 & 1 & 0 & 3 \\
\hline $\mathrm{A}_{12}$ & 0 & 1 & 3 & 4 & 4 & 0 & 1 & 4 & 3 & 1 & 1 & 0 & 4 & 3 & 4 \\
\hline $\mathrm{A}_{13}$ & 1 & 1 & 4 & 1 & 4 & 0 & 1 & 4 & 1 & 1 & 3 & 0 & 0 & 0 & 2 \\
\hline $\mathrm{A}_{14}$ & 4 & 2 & 2 & 2 & 1 & 2 & 0 & 0 & 0 & 3 & 3 & 2 & 1 & 0 & 0 \\
\hline $\mathrm{A}_{15}$ & 4 & 0 & 3 & 3 & 0 & 2 & 3 & 2 & 1 & 4 & 0 & 0 & 0 & 2 & 0 \\
\hline
\end{tabular}

Fig. 3 contains the application of the DEMATEL model criteria, showing that: if D-R values are greater or equal to zero, port actors become the cause of influence over other port actors, and if D-R values are negative, port actors receive the influence effect. It is apparent that some actors of the Port Community represent technological risk: the Technological Enterprise which provides technological and information services to the Port Community; and the Customs Agency, owing its own technology, can widely control and inspect cargo in the port. These actors possess their own information systems to manage documentation, information and data linked to the business core activities of the port. On the other hand, there are private actors in the export and import logistics chain who are not directly related to the Port Community, as they are not integrated to the online technological platforms, they run the risk of loosing information, having inefficient coordination and communication with other actors, wasting time in documental management, among others. With regard to trade associations and labour unions, as they are not integrated to the technological and communication processes, they only receive the effects of the absence of intraoperative systems together with the few opportunities of training for workers.

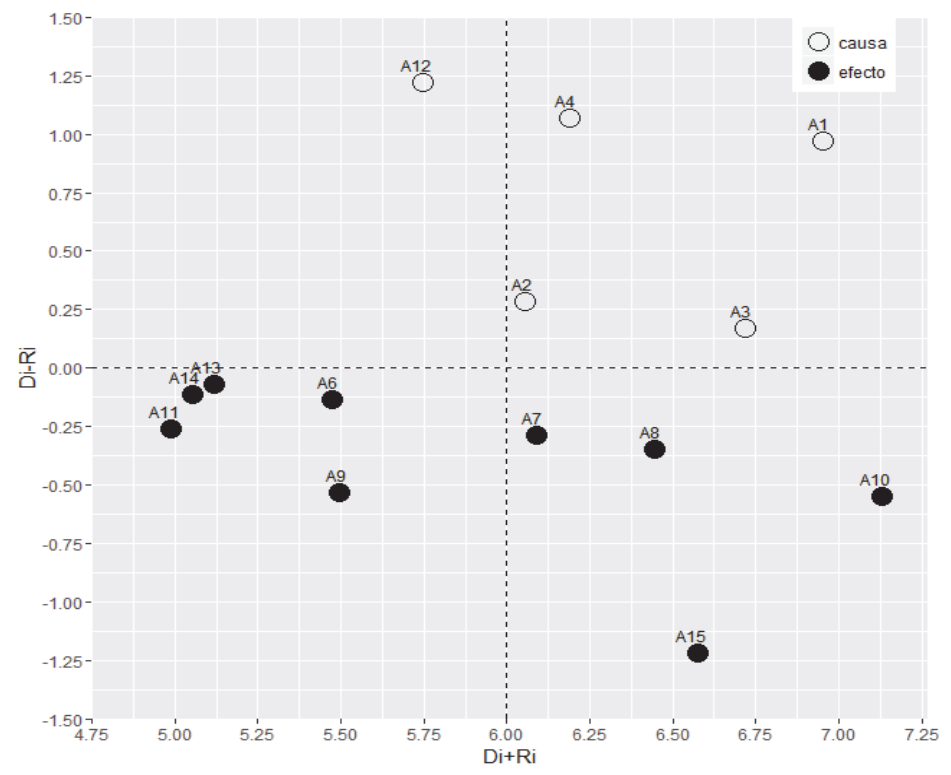

Fig. 3. Cause and effect diagram of the influence of technological risk 
It is observed that the results of DEMATEL coincide with port experts' points of view.

\section{Discussion}

\subsection{Gaps between DEMATEL and the communication technology process in export logistics chains}

When comparing DEMATEL results, which indicate those actors receiving and producing technological risk due to the absence of intraoperative systems, with the information diagram representing the information transference of the export process presented in Figure 4, it is possible to arrive at the conclusion that there are actors who do not express the technological and risk macro environment criteria in their strategic phrases (Durán \& Córdova, 2015).

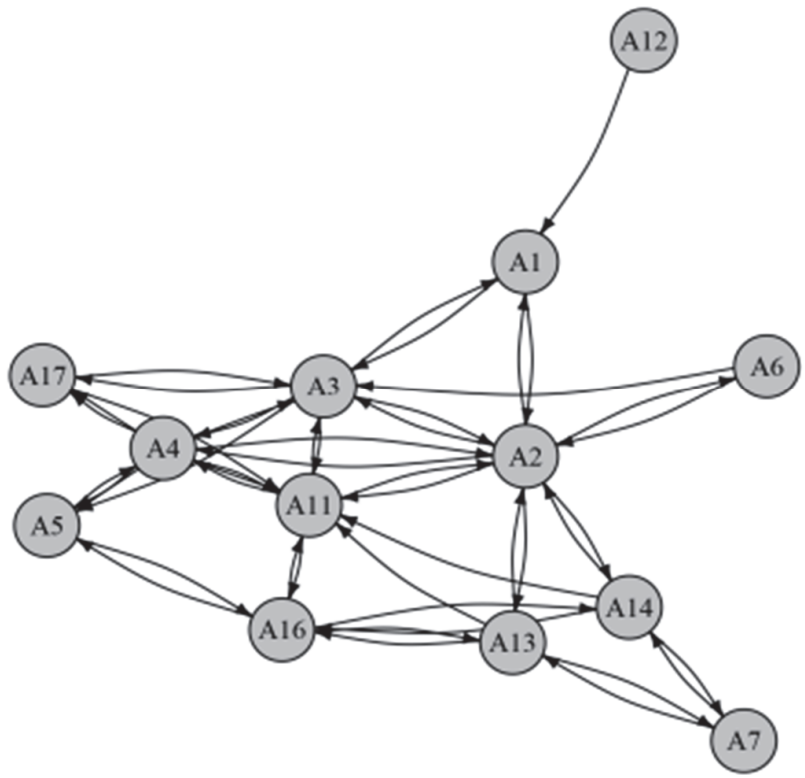

Fig. 4. Network of influence of information transfer in export logistics chains.

Adapted (Durán \& Córdova, 2015)

It should be observed that in this study the Storage and Containers Management Service $\left(\mathrm{A}_{16}\right)$ and Dockage Agency $\left(\mathrm{A}_{17}\right)$ actors, who transfer information linked with negotiation sub-processes, documental and Internal Port terminal coordination, are not included in this analysis, and they do not declare the technological and risk aspects in their strategic phrases (Durán \& Córdova, 2015). Likewise, it can be seen that the Labour Union and the Logistics Chain, The Labour Union and the trade association declare risk in their strategic phrases but no information transfer, which implies absence of linkage with the port technological platforms.

\subsection{Implications for engineering managers}

The results of this study can help engineering managers of the Port Authority to make strategic decisions that reduce the technological risk of the Port Community. It also shows how to identify risk and technology in strategies and objectives of a network of actors. Besides, it brings new knowledge and provides professionals a new way to observe how risk influences the coordination and innovation of technological processes of port actors. Can serve as part of a diagnostic to indicate what the companies have to improve, for example, if they need to improve of control procedures to protect data and ensure authorized access to information. 
It is a contribution to the management of the Port Community and the State of Chile, since it is possible to obtain the management information more effectively and efficiently. It is noteworthy that the chilean port is state-owned and that the State by the port law, manages the investments made by the port community on innovative technologies.

On the other hand, the main limitation of this work is little research on technological risks in a network of companies. In the ports the risk is mainly associated with the management of the security of the port, so it is necessary that the engineers who make strategic and business decisions in the ports have a greater knowledge of this topic; it is recommended that in the future they can implement measures of management control such as indicators.

\section{Conclusions}

The actors chosen for this study are those declaring the technological and/or risk macro environment aspects in their strategic phrases. Their statements are excluding since the only actor expressing technology and risk aspects is the Port Authority, who plays the role of governance and coordinator of the Port Community. For strategic synergy may imply links and common purposes, it is not possible to analyse the strategic synergy of the Port Community from the two macro-environment aspects studied.

Synergy between the Port Community and the other actors is analysed from the declaration of attributes or characteristics in operational and business objectives; these represent the goals to be achieved by all the actors of the port system and which have been devised to make the Port Community activities more efficient and effective. With this analysis it is possible to study technological and risk synergy between the Port Community and the other actors involved in the port system.

Furthermore, accepting the fact that many factors may bring about technological risk in a port, the most relevant ones, and related to technological integration, have been chosen, which are also in accord with port experts opinion. In this case, there is a direct relationship between technological integration and risk caused by the lack of coordination among actors; this situation could be overcome if the Port Community increased its investment in technological innovation. It is particularly relevant that the State of Chile, owner of the port, grants private enterprises the concession to administer and operate the terminals; for this reason the port depends on public financing and the concession policies developed. On the other hand, these decisions directly affect labour unions and trade associations since labour terms and conditions may be altered.

Finally, in order to improve port competitiveness it is necessary to integrate the technological and risk macro-environment criteria in the strategic phrases of all and every actor involved in the export logistics chain.

\section{Acknowledgments}

This work was supported by DICYT USACH Project. Universidad de Santiago de Chile.

\section{References}

Bank, W. (2008). Developing countries must improve capacity to absorb and use technology. International Financing.

Bayaga, A., \& Flowerday, S. (2012). Principal Causes of Information Communication Technology (ICT) Risk Failure in an SME. In 2012 International Conference on Cyber Security (pp. 152-156). IEEE. https://doi.org/10.1109/CyberSecurity.2012.26

Chien, K.-F., Wu, Z.-H., \& Huang, S.-C. (2014). Identifying and assessing critical risk factors for BIM projects: Empirical study. Automation in Construction, 45, 1-15. 
Chiu, Y.-J., Chen, H.-C., Tzeng, G.-H., \& Shyu, J. Z. (2006). Marketing strategy based on customer behaviour for the LCD-TV. International Journal of Management and Decision Making, 7(2-3), $143-165$.

Corning, P. (2003). Nature's Magic: Synergy in Evolution and the Fate of Humankind. Technological Forecasting and Social Change, 71, 653-660. https://doi.org/10.1016/j.techfore.2003.12.001

Durán, C., \& Córdova, F. (2015). Synergy and Technology Gaps in Export Logistics Chains between a Chilean and a Spanish medium-sized Port. Procedia Computer Science, 55, 632-641. https://doi.org/10.1016/j.procs.2015.07.055

Durán, C., \& Córdova, F. (2016). Analysis of synergic relationship in a Chilean medium-sized port: An approach from the simulation of the transformation matrix of eigenvalues. In Computers Communications and Control (ICCCC), 2016 6th International Conference on (pp. 196-200). IEEE.

Espinosa, F., \& Salinas, G. (2013). Selección de Estrategias de Mejoramiento de las Condiciones de Trabajo para la Función Mantenimiento Utilizando la Metodología MCDA Constructivista. Información Tecnológica, 24(3), 57-72. https://doi.org/10.4067/S0718-07642013000300008

Falatoonitoosi, E., Leman, Z., Sorooshian, S., \& Salimi, M. (2013). Decision-making trial and evaluation laboratory. Research Journal of Applied Sciences, Engineering and Technology, 5(13), 3476-3480.

Govindan, K., \& Chaudhuri, A. (2016). Interrelationships of risks faced by third party logistics service providers: A DEMATEL based approach. Transportation Research Part E: Logistics and Transportation Review, 90, 177-195. https://doi.org/10.1016/j.tre.2015.11.010

Hemati, M., Danaei, A., \& Shahhosseini, M. (2012). An empirical study to measure the relative efficiency and strategic planning using BSC-DEA and DEMATEL. Management Science Letters, 2(4), 1109-1122.

Hu, H.-Y., Chiu, S.-I., Cheng, C.-C., \& Yen, T.-M. (2011). Applying the IPA and DEMATEL models to improve the order-winner criteria: A case study of Taiwan's network communication equipment manufacturing industry. Expert Systems with Applications, 38(8), 9674-9683.

Kaplan, R., \& Norton, D. (2001). The strategy-focused organization: how balanced scorecard companies thrive in the new business environment. Harvard Business School Press.

Katsigeras, C. (2011). Iliana Christodoulou-Varotsi: Maritime safety law and policies of the European Union and the United States of America: antagonism or synergy? Aegean Review of the Law of the Sea and Maritime Law, 1(2), 313-314. https://doi.org/10.1007/s12180-011-0022-x

Knowles, S. (2014). Engineering Risk and Disaster: Disaster-STS and the American History of Technology. Engineering Studies, 6(3), 227-248.

Lin, Y.-T., Yang, Y.-H., Kang, J.-S., \& Yu, H.-C. (2011). Using DEMATEL method to explore the core competences and causal effect of the IC design service company: An empirical case study. Expert Systems with Applications, 38(5), 6262-6268. https://doi.org/10.1016/j.eswa.2010.11.092

Malina, M. A., Nørreklit, H. S. O., \& Selto, F. H. (2007). Relations among measures, climate of control, and performance measurement models. Contemporary Accounting Research, 24(3), 935-982.

Moghaddam, N. B., Sahafzadeh, M., Alavijeh, A. S., Yousefdehi, H., \& Hosseini, S. H. (2011). Strategic Environment Analysis Using DEMATEL Method Through Systematic Approach. Management Science and Engineering, 4(4), 95-105.

Orman, L. V. (2013). Technology as risk. IEEE Technology and Society Magazine, 32(2), 22-31.

Piggin, R. S. H. (2014). Governance, risk and compliance: impediments and opportunities for managing operational technology risk in industrial cyber security and safety. In System Safety and Cyber Security (2014), 9th IET International Conference on (pp. 1-8). IET.

Poveda-Bautista, R., Baptista, D. C., \& García-Melón, M. (2012). Setting competitiveness indicators using BSC and ANP. International Journal of Production Research, 50(17), 4738-4752.

Renn, O., \& Benighaus, C. (2013). Perception of technological risk: insights from research and lessons for risk communication and management. Journal of Risk Research, 16(3-4), 293-313.

Rodríguez, A., Ortega, F., \& Concepción, R. (2017). An intuitionistic method for the selection of a risk management approach to information technology projects. Information Sciences, 375, 202-218.

Scheer, D. (2013). Risk governance and emerging technologies: learning from case study integration. 
Journal of Risk Research, 16(3-4), 355-368.

Stankiewicz, P. (2009). The role of risks and uncertainties in technological conflicts: Three strategies of constructing ignorance. Innovation-The European Journal of Social Science Research, 22(1), 105-124.

Sumrit, D., \& Anuntavoranich, P. (2013). Using DEMATEL method to analyze the causal relations on technological innovation capability evaluation factors in thai technology-based firms. nternational Transaction Journal of Engineering, Management, \& Applied Sciences \& Technologies 4(2), 81103.

Todt, O., \& Luján, J. L. (2008). A new social contract for technology?-On the policy dynamics of uncertainty. Journal of Risk Research, 11(4), 509-523.

Wang, W.-C., Lin, Y.-H., Lin, C.-L., Chung, C.-H., \& Lee, M.-T. (2012). DEMATEL-based model to improve the performance in a matrix organization. Expert Systems with Applications, 39(5), 49784986. https://doi.org/10.1016/j.eswa.2011.10.016

Wei, H. (2010). Cooperation and Competition of Interfirm Network Organizations: The Function of Synergies. In 2010 International Conference on E-Business and E-Government (pp. 2339-2342). IEEE. https://doi.org/10.1109/ICEE.2010.591

Wu, H.-H., Shieh, J.-I., Li, Y., \& Chen, H.-K. (2010). A combination of AHP and DEMATEL in evaluating the criteria of employment service outreach program personnel. Information Technology Journal, 9(3), 569-575.

$\mathrm{Wu}, \mathrm{H} .-\mathrm{Y}$. (2012). Constructing a strategy map for banking institutions with key performance indicators of the balanced scorecard. Evaluation and Program Planning, 35(3), 303-320.

Wu, W.-W., \& Lee, Y.-T. (2007). Developing global managers' competencies using the fuzzy DEMATEL method. Expert Systems with Applications, 32(2), 499-507.

Young, C. S. (2016). Information Technology Risk Measurements and Metrics BT. In Information Security Science, Measuring the Vulnerability to Data Compromises (pp. 263-285). Syngress. https://doi.org/http://dx.doi.org/10.1016/B978-0-12-809643-7.00012-7

Zhong, M., Wu, Y., \& Luan, W. (2011). Model of synergy degree between port logistics and urban economy. Journal of Dalian Maritime University, 37(1), 80-82.

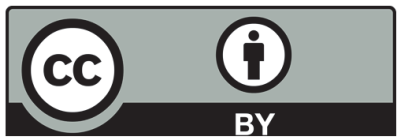

(C) 2018 by the authors; licensee Growing Science, Canada. This is an open access article distributed under the terms and conditions of the Creative Commons Attribution (CC-BY) license (http://creativecommons.org/licenses/by/4.0/). 